UDC 624.016.07

\title{
ENGINEERING METHOD FOR CALCULATING STEEL-REINFORCED CONCRETE ELEMENTS WITH FLEXIBILITY
}

\author{
Yefimenko Olena ${ }^{1 *}$ \\ ${ }^{1}$ Poltava National Technical Yuri Kondratyuk University https://orcid.org/0000-0001-5949-623X \\ *Corresponding author E-mail: Lenysia_17.02@ukr.net
}

In the article presents an engineering method for calculating compressed flexible reinforced concrete elements with sheet reinforcement over a steel cross section. The results of the calculation are compared with the experimental data. Calculation of load-bearing capacity of reinforced concrete flexible elements with sheet reinforcement is based on the method of boundary states. The work of specimens under load and the nature of the load-bearing capacity depending on the height and eccentricity of the effort were investigated. The proposed method of calculating compressed elements with sheet reinforcement on a steel-cross-section allows to take into account their flexibility in both axial and out-of-center application of load.

Keywords: steel reinforced concrete, bearing capacity, sheet reinforcement, eccentricity, flexibility

\section{ІНЖЕНЕРНИЙ МЕТОД РОЗРАХУНКУ СТАЛЕЗАЛІЗОБЕТОННИХ СТИСНУТИХ ЕЛЕМЕНТІВ З УРАХУВАННЯМ ГНУЧКОСТІ}

\author{
Сфіменко О.I. * \\ ${ }^{1}$ Полтавський національний технічний університет імені Юрія Кондратюка \\ *Адреса для листування E-mail: Lenysia_17.02@ukr.net
}

\begin{abstract}
Наведено інженерний метод розрахунку стиснутих гнучких сталезалізобетонних елементів з листовим армуванням за зведеним до сталі перерізом, а також порівняння результатів розрахунку з експериментальними даними. Розрахунок несучої здатності сталезалізобетонних гнучких елементів з листовим армуванням грунтується на методі граничних станів. Як граничний стан за міцністю прийнято зусилля, в результаті дії яких у листовому армуванні в найбільш напруженому волокні поздовжні деформації досягають значення, що відповідають напруженням плинності сталі. У розрахунок за методом зведених перерізів покладено передумови, що бетон, метал листового та стержньового армування вважаємо ізотропними пружно-пластичними матеріалами, а поперечний переріз сталезалізобетонного елемента 3 листовим армуванням залишається плоским аж до моменту руйнування. При розрахунку центрально стиснутих сталезалізобетонних елементів із листовим армуванням несуча здатність визначено шляхом зведення комплексного поперечного перерізу до односкладового - сталевого. Це дає змогу використовувати у розрахунку табличні коефіцієнти поздовжнього згину $\varphi$. Несуча здатність позацентрово стиснутого сталезалізобетонного елемента з листовим армуванням також визначається шляхом зведення комплексного поперечного перерізу до односкладового - сталевого. При цьому виникає можливість використовувати при розрахунках табличні значення коефіцієнта поздовжнього згину $\varphi_{\mathrm{e}}$, які містяться у ДБН. Експериментально було досліджено роботу зразків під навантаженням та характер втрати несучої здатності залежно від висоти й ексцентриситету прикладених зусиль. Запропонована методика розрахунку стиснутих елементів з листовим армуванням за зведеним до сталі перерізом дозволяє враховувати їх гнучкість як при осьовому, так і позацентровому прикладанні навантаження.
\end{abstract}

Ключові слова: сталезалізобетон, несуча здатність, листове армування, ексцентриситет, гнучкість 


\section{Introduction}

When calculating the elements working on compression, the problem is to consider their flexibility. This issue remains unresolved for steel reinforced concrete elements reinforced with sheets.

Review of the research sources and publications The engineering method for calculating steel-reinforced concrete elements with sheet reinforcement for a steel-cut cross-section was presented in DBN [1]. Prior to this work, compressed elements with reinforcing sheets of $4 \mathrm{~mm}$ thickness were investigated and height up to $1 \mathrm{~m} \mathrm{[3]}$ and elevation to $2.4 \mathrm{~m} \mathrm{[4].}$

\section{Definition of unsolved aspects of the problem}

This paper addresses the issue of calculating compressed flexible elements reinforced with sheets by cutting the cross section to steel.

\section{Problem statement}

The purpose of the article is to compare the results of theoretical studies with the engineering method of calculation of central and noncentrally compressed flexible reinforced concrete elements with sheet reinforcement in a steel-cross section.

\section{Basic material and results}

The calculation of the bearing capacity of steel reinforced concrete flexible elements with sheet reinforcement is based on the method of boundary states. As the ultimate state of strength it is taken the effort that as a result of which the sheet reinforcement in the most intense fiber longitudinal deformations reach values that correspond to the stress of steel flux.

The following assumptions are based on the calculation of the consolidated sections:

- concrete, metal sheet reinforcement and rod reinforcement are considered as isotropic elastic-plastic materials;

- we believe that the cross-section of steel-reinforced concrete element with sheet reinforcement remains flat until the moment of destruction;

- geometrical and physical-mechanical characteristics of steel and concrete we accept steel-length steelreinforced concrete element;

- during the entire work of the integrated section, concrete, sheet reinforcement and core reinforcement deform jointly;

- in the limiting state with centrifugal compression, the ambiguous string of stresses for concrete, sheet reinforcement and rod reinforcement in compressed and stretched zones has the shape of a rectangle;

- concrete of a stretched zone is not considered in the section of steel-reinforced concrete element with sheet reinforcement;

- rod reinforcement, if it is in conditions of one-piece compression or stretching.

When calculating the centrally compressed steel-reinforced concrete elements with sheet reinforcement, the bearing capacity can be determined by the construction of a complex cross-section to a single-component
- steel. In addition, it enables to use of tablewise coefficients of longitudinal bending in the calculation $\varphi$. In this formulation the question of the bearing capacity of steel-reinforced concrete element with sheet reinforcement is determined by the formula

$$
N=\varphi R_{s} A_{\text {zved }},
$$

where $A_{\text {zved }}$ - cross-sectional area, reduced to sheet metal reinforcement area (Fig. 1).

In this case, the aggregate area is calculated by the formula

$$
A_{z v e d}=A_{b} \frac{R_{b}}{R_{s}}+A_{s}+A_{s 1} \frac{R_{s 1}}{R_{s}},
$$

Coefficient $\varphi$ is determined by the addition of $\mathrm{K}$ to DBN [1] depending on flexibility $\lambda$ and the strength of sheet steel reinforcement $R_{s}$.

Flexibility of the element is calculated by the formula

$$
\lambda=\frac{L_{0} \mu}{i_{\text {zved }}},
$$

where $L_{0}$ free length of steel reinforced concrete condensed element with sheet reinforcement;

$\mu$ - coefficient of estimated length;

$i_{\text {звед }}$ - the radius of inertia of the cross-section of steelreinforced concrete element with sheet reinforcement, reduced to steel sheet reinforcement, determined by the formula

$$
i_{\text {zved }}=\sqrt{\frac{I_{\text {zved }}}{A_{\text {zved }}}} .
$$

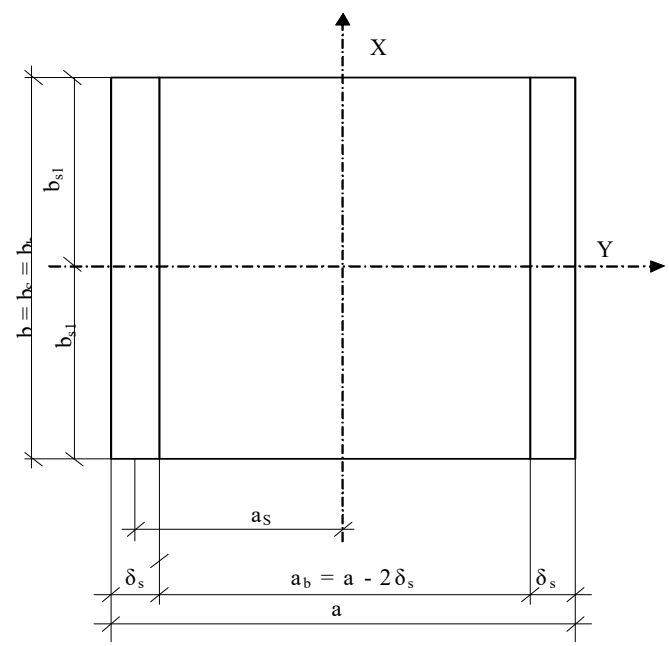

Figure 1 - Cross section of a steel concrete element with sheet reinforcement in the calculation for a steel-cut cross-section

With $A_{\text {zved }}$ is calculated by the formula (2), and the consolidated moment of inertia is calculated by the formula

$$
I_{\text {zved }}=I_{b} \frac{R_{b}}{R_{S}}+I_{S}+I_{s 1} \frac{R_{s 1}}{R_{S}} .
$$

Thus, in accordance with the proposed method, it is possible to determine the bearing capacity of centrally 
compressed steel reinforced concrete elements with sheet reinforcement using the instructions given in the DBN [1] tabular coefficients of longitudinal bending.

By analyzing the stress-strain state and the nature of the destruction of non-centered compressed steel reinforced concrete elements with sheet reinforcement, it can be concluded that they are highly dependent on eccentricity $e_{0}$. In this case, it is distinguished between two cases of the boundary state of the bearing capacity with centrifugal compression $\left(e_{0}>0\right)$ :

- the load is applied with eccentricity, but within the core of the cross-section (case of small eccentricities). In this case, the cross-section is completely compressed, but the destruction occurs in the tensest zone due to the bending of sheet reinforcement. All this leads to the non-use of the strength of the less compressed part of the cross-section;

- the load is applied with large values of eccentricity, that is, beyond the core of the cross-section (case of large eccentricities). In this case, the longitudinal axis is significantly distorted and there is a stretched zone in the transverse section.

The bearing capacity of a noncentrally compressed steel reinforced concrete element with sheet reinforcement can be determined by the construction of a complex cross-section to a single-component - steel. In this case, it is possible to use in the calculations table values of the coefficient of longitudinal bending $\varphi_{\mathrm{e}}$, which are contained in DBN [1]. In this case, the calculation formula for determining the bearing capacity of the centrifugally compressed steel reinforced concrete element with sheet reinforcement has the form

$$
N=\frac{R_{S}}{\frac{1}{A_{\text {zved }}}+\frac{e_{0} y_{\max }}{I_{x(y), \text { zved }}}},
$$

where $A_{\text {zved }}$ - the area of the cross-section, reduced to the area of metal sheet reinforcement, is determined by the formula (2);

$y_{\max }$ - the distance from the center of gravity of the consolidated cross-section to the most stretched fiber;

$I_{x(y), \text { zved }}$ - the combined moment of inertia of the crosssection relative to the central axes, is determined by the formula

$$
I_{x(y), \text { zved }}=I_{x(y), b} \frac{R_{b}}{R_{S}}+I_{x(y), s 1} \frac{R_{s 1}}{R_{S}},
$$

where $I_{x(y), b}, I_{x(y), s}, I_{x(y), s 1}-$ moments of inertia of concrete, metal sheet reinforcement and metal rod reinforcement relative to center of gravity axes $\left(\mathrm{X}_{0}\right.$ and $\left.\mathrm{Y}_{0}\right)$ convex cross-section (Fig. 1).

The corresponding moments of inertia of the crosssectional components areas are determined (Fig. 1) according to the formula

$$
\begin{gathered}
I_{X, b}=I_{X_{b}}=\frac{b a_{b}^{3}}{12} ; \\
I_{Y, b}=I_{Y_{b}}=\frac{a b^{3}}{12} ;
\end{gathered}
$$

$$
\begin{aligned}
& I_{X, S}=2\left[I_{X S}+a_{S}^{2} A_{S}^{1}\right]=2\left[\frac{b \delta_{s}^{3}}{12}+a_{S}^{2} A_{S}^{1}\right] \\
& I_{Y, S}=2 I_{Y_{S}}=2 \frac{\delta_{s} b^{3}}{12} \\
& I_{X, s 1}=4\left[I_{X}+a_{s 1}^{2} A_{s 1}^{1}\right]=4\left[\frac{\pi d_{s 1}^{3}}{64}+a_{s 1}^{2} A_{s 1}^{1}\right] \\
& I_{Y, s 1}=4\left[I_{Y_{s 1}}+b_{s 1}^{2} A_{s 1}^{1}\right]=4\left[\frac{\pi d_{s 1}^{3}}{64}+b_{s 1}^{2} A_{s 1}^{1}\right]
\end{aligned}
$$

where $\left(X_{b}, Y_{b}\right),\left(X_{s}, Y_{s}\right),\left(X_{s l}, Y_{s l}\right),-$ own concrete axes, sheet reinforcement and rod reinforcement in the cross section of steel reinforced concrete element with sheet reinforcement, respectively;

$A_{s}{ }^{l}, A_{s}{ }^{l}$ - cross-sectional area of one element of sheet reinforcement and one element of rod reinforcement in cross-section of steel-reinforced concrete element with sheet reinforcement.

The calculation for the stability of non-centrifugally compressed elements of the constant in length of the cross-section in the plane of action of the bending moment, which coincides with the plane of symmetry, should be performed according to the formula

$$
\frac{N}{\varphi_{e} A_{z v e d} R_{y} \gamma_{c}} \leq 1 \text {. }
$$

In the formula (14) stability factor for off-center compression $\varphi_{e}$ should be determined by table K.3 application K DBN [1] depending on the values of conditional flexibility $\bar{\lambda}$ and the reduced relative eccentricity $m_{e f}$, which is calculated by the formula

$$
m_{e f}=\eta m
$$

where $\eta$ - coefficient of section shape influence of should be determined by table K.2 application $\mathrm{K}$ DBN [1];

$m=e A / W_{c}-$ relative eccentricity;

$e=M / N-$ eccentricity, when calculating the estimated values of internal effort $M$ and $N$ should be taken in accordance with the requirements DBN [1]; $W_{c}$ - moment of resistance of the cross section, calculated for the most compressed fiber.

The value of the coefficient of longitudinal bending $\varphi_{e}$ is set according to DBN [1] depending on the design resistance of steel sheet reinforcement $R_{y}$ and flexibility $\bar{\lambda}$. The aggregate flexibility is determined by the formula

$$
\bar{\lambda}=\lambda \sqrt{\frac{R_{y}}{E}} .
$$

Value of coefficients $\varphi$ is shown in table $\mathrm{K} 1$ application K DBN [1].

The bends of the average height of the cross-section of flexible steel reinforced concrete structures with sheet reinforcement can be determined on the basis of the condition 


$$
M=N\left(e_{0}+f\right)=\frac{N_{e_{0}}}{1-\frac{N}{N_{\text {gran }}}},
$$

where $M$ - moment acting in cross-section;

$N$ - longitudinal effort;

$N_{\text {gran }}$ - conditional limiting force perceived by the design

$$
N_{\text {gran }}=\frac{\pi^{2} E_{S} I_{\text {zved }}}{L^{2}} .
$$

a)

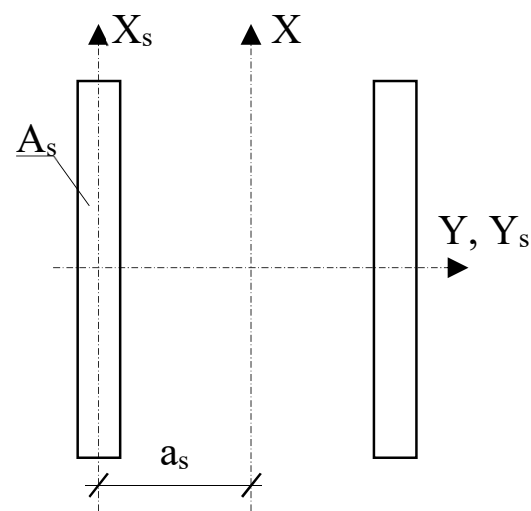

h)

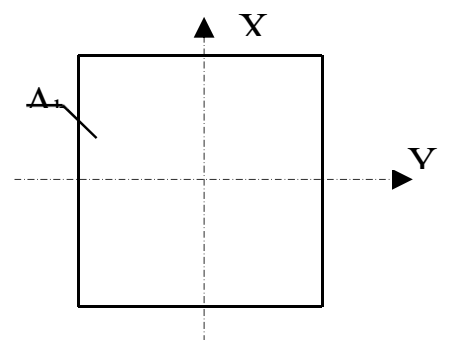

Figure 2 - Scheme of cross-section of steel-reinforced concrete element with sheet reinforcement, with defined moments of inertia of component parts: $\mathrm{a}$ - sheet reinforcement; $\mathrm{b}$ - concrete

Substituting (18) in (17) and decided the equation relative $f$, it is obtained a formula for determining the complete bending of steel reinforced concrete structures with sheet reinforcement in compression:

$$
f_{x(y)}=\frac{G \pi^{2} e_{0}}{G \pi^{2}-N L^{2}}-e_{0},
$$

where $G$ - rigidity of steel reinforced concrete structure with sheet reinforcement:

$$
G=E_{S} I_{x(y), \text {, ved }}
$$

where $E_{s}$ - modulus of elasticity of sheet metal reinforcement.

In the table 1 the research experimental data of steel reinforced concrete elements with sheet reinforcement bearing capacity are given [4]. For the study samples were made in different heights and different applied ec- centricity. The process of manufacturing steel reinforced concrete elements consisted of two parts: the

\begin{tabular}{|c|c|c|c|c|c|}
\hline $\begin{array}{l}\text { Sample } \\
\text { series }\end{array}$ & 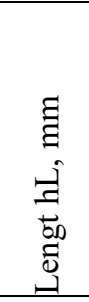 & 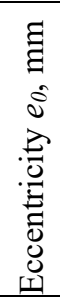 & 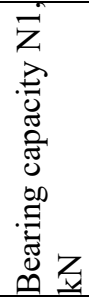 & 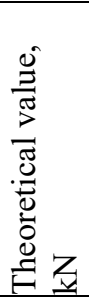 & 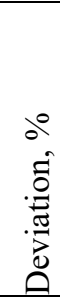 \\
\hline SB-PD-10-1 & 1000 & 0 & 238 & 219 & 8.0 \\
\hline SB-PD -10-2 & 1000 & 25 & 154 & 146 & 5.2 \\
\hline SB-PD -10-3 & 1000 & 50 & 105 & 101 & 3.8 \\
\hline SB-PD -17-1 & 1700 & 0 & 234 & 223 & 4.7 \\
\hline SB-PD -17-2 & 1700 & 25 & 144 & 132 & 8.3 \\
\hline SB-PD -17-3 & 1700 & 50 & 93 & 86 & 7.5 \\
\hline SB-PD -24-1 & 2400 & 0 & 211 & 198 & 6.2 \\
\hline SB-PD -24-2 & 2400 & 25 & 148 & 136 & 8.1 \\
\hline SB-PD -24-3 & 2400 & 50 & 102 & 93 & 8.8 \\
\hline
\end{tabular}
manufacture of steel frames and concrete concreting.

Table 1 - Results of comparison of calculations of bearing capacity

For the production of experimental samples, section of which is given on Fig. 3, steel sheet was used $\mathrm{t}=4 \mathrm{~mm}$, cross-section valves of a class A-I $\varnothing 6 \mathrm{~mm}$. The sample height was at $1000,1700,2400 \mathrm{~mm}$, section $100 \times 100 \mathrm{~mm}$. To find out the effectiveness of the work of steel-concrete elements, a sample of steel without concrete height was tested $1000 \mathrm{~mm}$. Standard concrete concrete cubes were tested for determination of physical and mechanical properties of concrete aggregate $150 \times 150 \times 150 \mathrm{~mm}$ and prisms $150 \times 150 \times 600 \mathrm{~mm}$, made from the same concrete as the prototype.

When tested, experimental specimens had a different bearing capacity, which depended on the constructive solution of the load application eccentricity (Fig. 4). a)

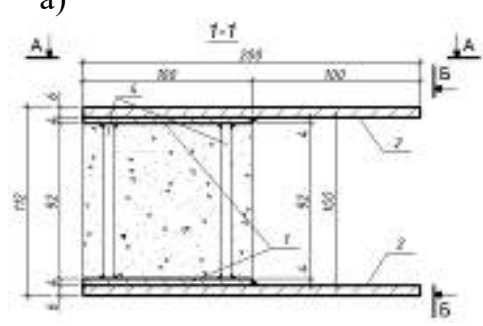
a - in the supporting part; $\mathrm{b}-$ in the middle of the sample

\section{Figure 3 - Breakdown of experimental samples:}

b)

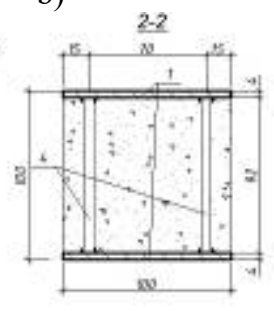




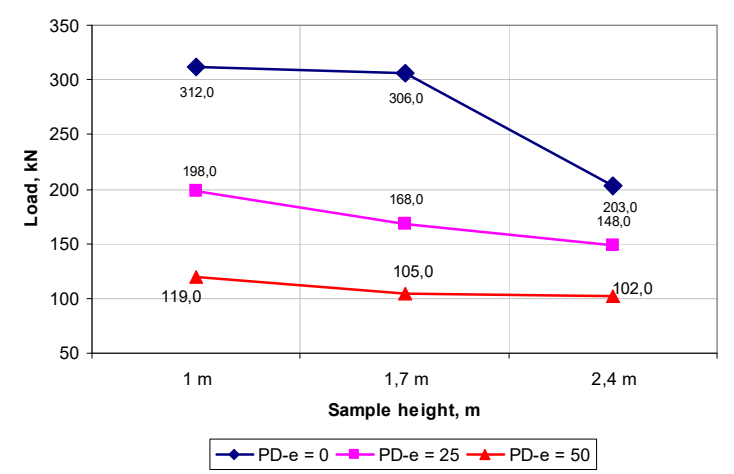

Figure 4 - Dependence of tested steel-reinforced concrete samples with sheet reinforcement carrying capacity on element height

The work of the samples under load and the nature of the bearing capacity loss depending on the height and eccentricity of the applied efforts have been experimentally investigated.
In the course of experimental studies, longitudinal and transverse deformations were measured at different distances from the ends of the element, as well as the displacement of the average height at the cross-section. All this enabled to get a complete picture of the work under the load of steel concrete racks with sheet reinforcement both at central and centripetal compression.

In the table 1 the comparison results of calculated values of load bearing capacity of compressed flexible steel reinforced concrete elements with results of experimental research are given.

\section{Conclusions}

The proposed method of calculation of compressed elements with sheet reinforcement in a steel-cut crosssection enables to consider their flexibility both in axial and centrifugal loading. The theoretical values of the bearing capacity are satisfactory with the results of the experiment, the difference is no more than $8.8 \%$.

\section{References}

1. ДБН В.2.6-163:2010 (2011). Сталеві конструкиіï. Норми проектування, виготовлення $і$ монтажу. Київ: Міненергобуд України.

2. Eurocode 4: Bemessung und Konstruktion von Verbund tragwerken ans ftahl und Beton. - E №V 1994.

3. Биба, В.В. (2006). Стиснені сталезалізобетонні елементи з листовим армуванням (Автореф. дис. канд. техн. наук), Полтава, ПолтНТУ.

4. Storozhenko, L.I., Murza, S.O., Yefimenko, O.I. (2010). Capacity flexible compressed reinforced concrete elements reinforced with steel sheets. Academic journal. Industrial Machine Building, Civil Engineering. Potava: PoltNTU, 1(50), 79-87.

https://doi.org/10.26906/znp.2018.50.1062

5. Gasii, G., Zabolotskyi O. (2017). Constructive concept of composite structures for construction including geological specifics. Budownictwo o zoptymalizowanym potencjale energetycznym. Częstochowa: Wydawnictwo Politechniki Częstochowskiej, 20(2), 37-42.

https://doi.org/10.17512/bozpe.2017.2.05.

6. Гасій, Г.М. (2017). Експериментально-теоретичні дослідження напружено-деформованого стану плити структурно-вантової сталезалізобетонної конструкиії. Збірник наукових праць Українського державного університету залізничного транспорту, 170(4), 72-78.

https://doi.org/10.18664/1994-7852.170.2017.111286

7. Стороженко, Л.І., Гасій, Г.М. (2017). Визначення переміщень вузлів просторової структурно-вантовоі стале-залізобетонної конструкиії експериментальним шляхом. Збірник наукових праць Українського державного університету залізничного транспорту,. 169(3), 118128.

https://doi.org/10.18664/1994-7852.169.2017.111090

8. Gasii, G.M. (2017). Finite element analysis of the stress and strain state of the node of the top belt of the steel and concrete composite cable space frame. Collection of scientific works of the Ukrainian State University of Railway Transport. Kharkiv: UkrSURT, 171(5), 69-76.

https://doi.org/10.18664/1994-7852.171.2017.111429
1. DBN B.2.6-163:2010 (2011). Steel structures. Norms of designing, manufacturing, installation. Kyiv: Ministry of Energy of Ukraine.

2. Eurocode 4: Bemessung und Konstruktion von Verbund tragwerken ans ftahl und Beton. - E №V 1994.

3. Biba, V.V. (2010). Compressed reinforced concrete elements with sheet reinforcement (Master's thesis). Poltava, PoltNTU.

4. Storozhenko, L.I., Murza, S.O., Yefimenko, O.I. (2010). Capacity flexible compressed reinforced concrete elements reinforced with steel sheets. Academic journal. Industrial Machine Building, Civil Engineering. Potava: PoltNTU, 1(50), 79-87.

https://doi.org/10.26906/znp.2018.50.1062

5. Gasii, G., Zabolotskyi O. (2017). Constructive concept of composite structures for construction including geological specifics. Budownictwo o zoptymalizowanym potencjale energetycznym. Częstochowa: Wydawnictwo Politechniki Częstochowskiej, 20(2), 37-42.

https://doi.org/10.17512/bozpe.2017.2.05.

6. Gasii, G.M. (2017). Experimental and theoretical investigations of stress-strain state of the slab of the steel and concrete composite cable space frame. Collection of scientific works of the Ukrainian State University of Railway Transport, 170(4), 72-78

https://doi.org/10.18664/1994-7852.170.2017.111286

7. Storozhenko, L.I., Gasii, G. (2017). Determination displacement of nodes of the steel and concrete composite cable space frames by experimentation. Collection of scientific works of the Ukrainian State University of Railway Transport, 169(3), 118-128.

https://doi.org/10.18664/1994-7852.169.2017.111090

8. Gasii, G.M. (2017). Finite element analysis of the stress and strain state of the node of the top belt of the steel and concrete composite cable space frame. Collection of scientific works of the Ukrainian State University of Railway Transport. Kharkiv: UkrSURT, 171(5), 69-76.

https://doi.org/10.18664/1994-7852.171.2017.111429 